\title{
Decision-making Processes in Introducing RFID Technology in Manufacturing Company
}

\author{
Jan Lizbetin \\ Institute of Technology and Business in \\ České Budějovice \\ Faculty of Technology, Department of \\ Transport and Logistics, Czech Republic \\ e-mail: lizbetin@mail.vstecb.cz
}

DOI 10.17818/NM/2018/4SI.23

UDK 621.39:337.71

Professional paper

Paper accepted: 28. 8. 2018.

\section{Summary}

The article deals with the application of modern automatic identification systems in manufacturing companies. Automatic identification is nowadays an integral part of any logistics chain, since it enables time and financial savings in managing material flow. In particular, the article focuses on the radiofrequency technology and shows one of the possible standpoints on the decision-making processes in the individual stages of application of the technology. It points to the possible application of exact mathematical methods in solving practical problems. The first part of the article focuses on the possible application and use of the RFID technology in a chosen unnamed company consisting of the automated loading of data on the incoming flow of raw material into the warehouse. The second part of the article deals with a practical application of selected exact methods in the decision-making processes when introducing new technologies in the company. The author of the article points out that the processes and methods described represent only one of the possible solutions.

\section{INTRODUCTION}

In the context of providing logistics services and improving services in industry and commerce it is necessary to come up with new technologies that would put more emphasis on economic efficiency, safety and competitiveness. Nowadays, electronic transmission of data and digitalized retrieving of data from handling units are commonplace in logistics chains. Currently, there are a number of automatic identification technologies based on optic, radio frequency, inductive, magnetic or biometric principle. The technologies use passive or active elements of a logistics chain for transmitting information between the individual elements and operators of the whole logistics chain. They are used to record, identify and seek information, identify and seek objects, identify places, check status, monitor or manage the processes or transact processes [1], [2].

Radio Frequency Identification (RFID) is a non-contact automatic identification system for transmitting and storing data using electromagnetic waves [3]. The storage media have a form of identification labels (so-called transponders) or tags that may vary in the capacity. By means of electromagnetic waves, the data are transmitted to the antenna, from which the data are exported to readers, where they are decoded and exported to readers (or information system). Radio frequency technology is recommended to be used in an unclean environment (frosty, dusty, muddy, with chemically aggressive substances) or in the conditions where there is not possible to ensure visibility (that is, where there is not possible to use bar codes).
Although radio frequency technology is more expensive than e.g. bar codes, it is able to compete with them, especially in the USA) even in the areas where using bar codes has so far been predominant. The technology is seen as very promising especially for logistics systems. Its further dissemination will depend on the affordability of transponders as well as on the standardisation (at present, the major obstacle is in differing national regulations and legislative standards for allocating frequency the transponders can operate on [4-6].

\section{APPLICATION OF RFID TECHNOLOGY IN MANUFACTURING COMPANY}

The manufacturing company (unnamed) still uses bar codes (EAN) for recording information and data on incoming material and raw material into the database. Bar codes (most often Code 128 [7]) must be placed on a EUR palette, case or special crate by suppliers. In the company, the material (raw material) is unloaded onto the ramp and subsequently the data are loaded into the warehouse database using a portable EAN reader. By introducing the RFID technology in the company, the transmission of information to the corporate system could be more efficient due to the shorter time necessary for recording material entry into warehouse (bar code scanning will not be carried out), reducing the work of warehousemen and streamlining the storing process itself, since after reading the information from the transponders, the system will automatically store the item and allocate it an appropriate position in the warehouse. 
Practical application of the RFID technology in the company consists of the installation of RFID gate (or an antenna), that would automatically read and write the information from the RFID tags without the operator service required. Gates, or antennas, could transmit data of the incoming stock into the central warehouse computer via receiver interface so that it is possible to safely store all the data. The technology can be used with the EDI system that in cooperation with the RFID technology automatically orders goods from suppliers, i.e. the RFID sends the amount of material or raw material to the production process and the EDI writes the sent material off and automatically orders and sends the material from the supplier [8], [9]. The total cost incurred (RFID tags, RFID gates or antennas, software, RFID system and EDI system) is estimated at about 20 million CZK.

Central RFID system in the company would be set so that the RFID gates, RFID antennas and the central computer mutually communicate on the basis on the radio frequency waves. The system would be interconnected with the EDI technology that in cooperation with the RFID system would record the amount and condition of the goods received to the warehouse. It thus records the amount of the ordered material or raw material that was imported into the warehouse as input stock [10].

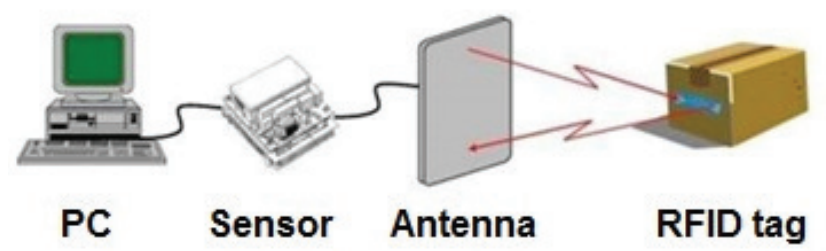

Source: http://www.gs1cz.org/ [online]

Figure 1 System of RFID technology

\section{DECISION-MAKING PROCESSES IN INTRODUCING RFID TECHNOLOGY}

When introducing a new technology it is important to compare the technology proposed with alternative technologies. In the decision-making processes, various exact methods from the decision theory can be used.

The proposed RFID technology can be compared with QR codes or Data Matrix codes. The comparison can be made using the WSA (Weight Sum Approach) method [11].

WSA is one of multi-criteria evaluation of variants. There must be more than 1 criterion, while there is no upper limit for the number of criteria. The rows show the individual variants, while columns contain the criteria. In the centre, there is evaluation of the variant [12], [13].

As the maximization criteria, the company has chosen the cost of acquisition, operating costs, stability and quality of technology. The minimization criterion is the cost of installation and operation of the system. This criterion is converted into maximization criterion. The weights of the individual criteria were chosen according to the Metfessel allocation method (the method of allocating 100 points) [14].
Table 1 WSA method

\begin{tabular}{|c|c|c|c|c|}
\hline Variants/ Criteria & K1 & K2 & K3 & K4 \\
\hline V1 & 0.2 & 0.822 & 1 & 1 \\
\hline V2 & 0.36 & 0.811 & 0.632 & 0.652 \\
\hline V3 & 0.51 & 0.836 & 0.532 & 0.131 \\
\hline Weights & 0.25 & 0.2 & 0.33 & 0.22 \\
\hline Evaluation & MAX & MIN & MAX & MAX \\
\hline
\end{tabular}

Source: author, based on [15]

Legend:

K1-cost of acquisition

K2 - cost of installation and operation of system,

K3-operating costs,

K4 - stability and quality of technology,

V1-RFID technology,

V2 - QR codes,

V3-Data Matrix.

Subsequently, the minimization criteria are converted into maximization criteria.

Table 2 Converting minimization criteria to maximization

\begin{tabular}{|c|c|c|c|c|}
\hline & K1 & K2 & K3 & K4 \\
\hline V1 & 0.2 & 0.014 & 1 & 1 \\
\hline V2 & 0.36 & 0.025 & 0.632 & 0.652 \\
\hline V3 & 0.51 & 0 & 0.532 & 0.131 \\
\hline
\end{tabular}

Source: author, based on [16], [17]

Ideal variant $\mathrm{H}=\{0.51 ; 0.025 ; 1 ; 1\}$

Basal variant $D=\{0.2 ; 0 ; 0.532 ; 0.131\}$ [18], [19]

Normalized matrix (see Table 3 ) is subsequently calculated as follows [20-23]:

$$
W_{i j}=\frac{G_{i j}-D_{j}}{H_{j}-D_{j}}
$$

Criterion 1:

$V 1=\frac{0.2-0.2}{0.51-0.2}=0 ; V 2=\frac{0.36-0.2}{0.51-0.2}=0.516 ; V 3=\frac{0.51-0.2}{0.51-0.2}=1$.

Criterion 2:

$V 1=\frac{0.014-0}{0.025-0}=0.56 ; V 2=\frac{0.025-0}{0.025-0}=1 ; V 3=\frac{0-0}{0.025-0}=0$.

Criterion 3:

$V 1=\frac{1-0.532}{1-0.532}=1 ; V 2=\frac{0.632-0.532}{1-0.532}=0.214 ; V 3=\frac{0.532-0.532}{1-0.532}=0$.

Criterion 4:

$V 1=\frac{1-0.131}{1-0.131}=1 ; V 2=\frac{0.652-0.131}{1-0.131}=0.599 ; V 3=\frac{0.131-0.131}{1-0.131}=0$.

Table 3 Creation and calculation of matrix of the WSA method calculation

\begin{tabular}{|c|c|c|c|c|}
\hline Variants/ Criteria & K1 & K2 & K3 & K4 \\
\hline V1 & 0 & 0.56 & 1 & 1 \\
\hline V2 & 0.516 & 1 & 0.214 & 0.599 \\
\hline V3 & 1 & 0 & 0 & 0 \\
\hline Weights & 0.25 & 0.2 & 0.33 & 0.22 \\
\hline
\end{tabular}

Source: author, based on [16], [17]

Subsequently, the values in the table are multiplied by the weights:

$V 1=(0.25 * 0)+(0.2 * 0.56)+(0.33 * 1)+(0.22 * 1)=\mathbf{0 . 6 6 2} ;$

$V 2=(0.25 * 0.516)+(0.2 * 1)+(0.33 * 0.214)+(0.22 * 0.599)=0.531$;

$V 3=(0.25 * 1)+(0.2 * 0)+(0.33 * 0)+(0.22 * 0)=0.25$ 
Based on the WSA method, the most appropriate seems to be the application of the RFID technology.

The company thus plans to introduce the RFID technology. However, it is necessary to decide whether to apply RFID tags during the coming/ transporting of the material by rail, that is to attach them to the wagons that belong to the rail carrier, or whether the RFID tags will be attached only to the transport units with material. In the first case, the information on the material flow would be loaded by means of RFID gate placed at the railway siding gate, in the second case the information would be loaded during the process of unloading wagons by means of antenna attached to the forklift trucks that transport the material to the warehouse. Another possibility is to place the RFID tags on the received palette units that would be automatically recorded into the database of the company systems by means of RFID antenna or warehouse RFID gate.

The question is whether the company should place the RFID gates (antennas) at the railway siding gate or later on the forklift trucks, or whether to place the RFID tags on the palette units after transporting the material to the warehouse and record them in the warehouse after transporting the material using various handling equipment, which is not a solution to the material reception optimization problem (only its next flow).

This problem can be solved by using the method of planning and forecasting assessment [24-27]. The company determined the score (1-10) and weights according to the following criteria (see Table 4).

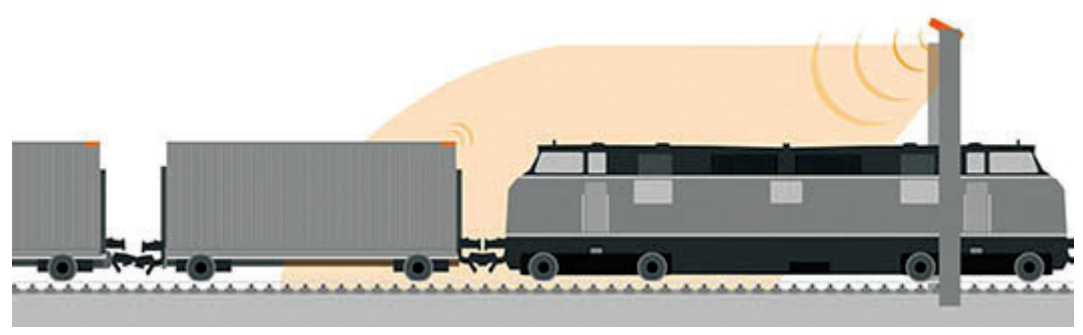

Source: http://geotekbs.com [online]

Figure 2 Application of RFID tags on wagons

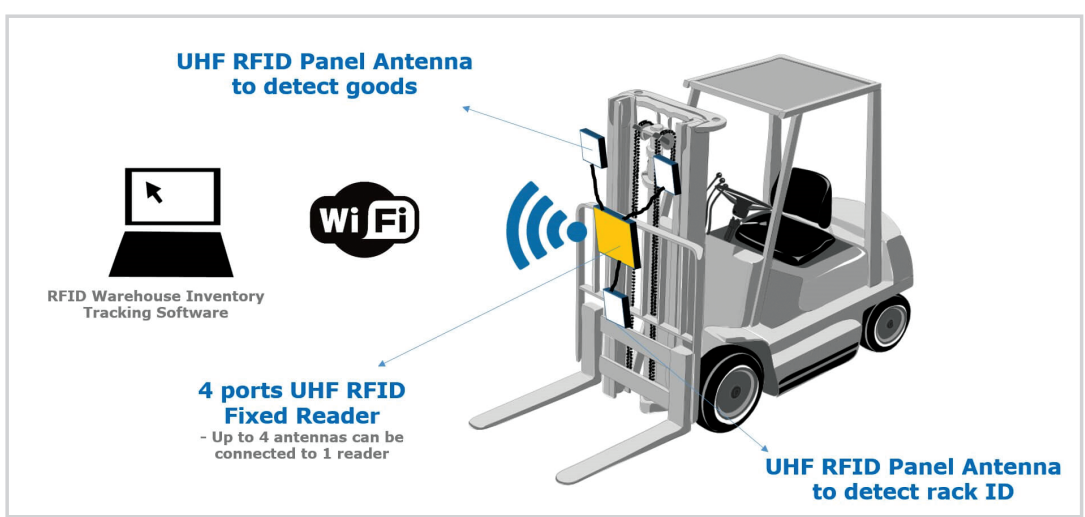

Source: https://ja-si.com/rfid-forklift-rack-management/ [online]

Figure 3 Application of RFID antenna on forklift trucks

Table 4 Calculation of method of planning and forecasting assessment

\begin{tabular}{|c|c|c|c|c|c|c|c|}
\hline \multirow{2}{*}{ Individual factors: } & \multirow{2}{*}{$\begin{array}{c}\text { Weight } \\
(\%)\end{array}$} & \multicolumn{3}{|c|}{ Score (1-10 points) } & \multicolumn{3}{|c|}{ Weighted score } \\
\hline & & ŽV & VV & PJ & V & V & PJ \\
\hline Cost of acquiring RFID technology (tags) & 0.12 & 7 & 6 & 4 & 0.84 & 0.72 & 0.48 \\
\hline Costs of equipping wagons with RFID tags & 0.28 & 9 & 7 & 5 & 2.52 & 1.96 & 1.4 \\
\hline Costs of equipping forklift trucks with RFID antennas & 0.10 & 7 & 6 & 4 & 0.7 & 0.6 & 0.4 \\
\hline Costs of equipping palettes with RFID tags & 0.06 & 6 & 5 & 4 & 0.36 & 0.3 & 0.24 \\
\hline Personnel costs & 0.13 & 8 & 8 & 8 & 1.04 & 1.04 & 1.04 \\
\hline Specialization of workers & 0.10 & 7 & 5 & 5 & 0.7 & 0.5 & 0.5 \\
\hline Usability of RFID tags & 0.20 & 8 & 8 & 7 & 1.6 & 1.6 & 1.4 \\
\hline \multicolumn{5}{|l|}{ In total: } & 7.76 & 6.72 & 5.46 \\
\hline
\end{tabular}

Source: author 
The calculation is as follows [28-30]:

Score ${ }^{*}$ weight $=$ weighted score;

Total weighted score $=\Sigma$ of weighted score of all factors.

Based on the results showed in Table 4, the best solution for the company is to equip railway wagons with RFID tags and place RFID gates (or antenna) at railway siding gate that would automatically record the data from the individual tags placed on each railway wagon [31-33].

\section{CONCLUSION}

Radiofrequency automatic identification enables companies to get a perfect real time overview of reception of the material in the warehouse, production and dispatch of consignments from the warehouse. Basic advantages of the system are improving the security / safety of the stock and eliminating repeated handling, which results in saving time and error elimination.

Despite all benefits of RFID technology, its application has not been fully used so far. The main obstacle is in missing/ nonexisting standardization of RFID bands from the global point of view. RFID systems operating in the UHF band are already in use and in the future they will be more and more used in logistics, identification and control of packaged products. It is the area where products are often transported all over the world, where it is necessary to ensure that it is possible to read the RFID tags produced and placed in Europe even in the USA, China or Australia. Unfortunately, very frequently used UHF communication frequency band varies from country to country and thereforeother frequencies have been allocated to the RFID. And this is the sticking point - different frequencies and incompatibility of the individual systems.

\section{REFERENCES}

[1] Choholac, J., Hrdy, D., Kuptcova, A., Prusa, P. Factors affecting the warehouse location with accent on communication with the extern entities. Logi Scientific Journal on Transport and Logistics, 2016, Vol. 7, No. 1, pp. 18 - 26. ISSN 1804-3216.

[2] Choi, T. M., Yeung, W. K., Cheng, T. C. E., Yue, X. H. Optimal Scheduling Coordination, and the Value of RFID Technology in Garment Manufacturing Supply Chains. IEEE Transactions on Engineering Management, 2018, Vol. 65, Issue: 1, pp. 72-84. ISSN 0018-9391.

[3] Vaculik, J., Michalek, l., Kolarovszki, P. Principles of Selection, Implementation and Utilization of RFID in Supply Chain Management. Promet - Traffic \& Transportation, 2009, Vol. 21, Issue 1, pp. 41-48. ISSN 0353-5320.

[4] Tan, X., Wang, H., Fu, L. Z., Wang, J. Y., Min, H., Engels, D. W. Collision Detection and Signal Recovery for UHF RFID Systems. IEEE Transactions on Automation Science and Engineering, 2018, Vol. 15, Issue 1, pp. 239-250. ISSN 1545-5955.

[5] Krile, S., Krile, M., Prusa, P.: Non-linear mini-max problem of multi-stop flight routes, Transport, 2015, Vol. 30, No 3, 2015, pp. 361-371. ISSN 1648-4142.

[6] Nedeliakova, E., Sekulova, J., Nedeliak, I. Risk management in the conditions of railway infrastructure manager. Ekonomicko-manazerske spektrum, 2014, Vol. 8, No 1, pp. 22-28

[7] Kolarovszki, P., Vaculik, J. Middleware - Software Support in Items Identification by Using the UHF RFID Technology. Mobile and Ubiquitous Systems: Computing, Networking and Services, 2014, Vol. 131, pp. 358-369. ISSN 1867-8211.

[8] Kral, P., Janoskova, K. Public sector comparator (PSC). Ekonomickomanazerske spektrum, 2013, Vol. 7, No 1, pp. 29-33.

[9] Kliestik, T. Optimization of Transport Routes Based on Graph Theory as a Part of Intelligent Transport Systems, In: 17th International Conference on Transport Means, Transport Means - Proceedings of the International Conference, 2013, pp. 308-311. ISSN 1822-296X.

[10] Závadský, J., Hitka, M., Potkány, M. Changes of employee motivation of slovak enterprises due to global economic crisis. E+M. Economics and Management, 2015, Vol. 18, No 1, pp. 57-66. ISSN 1212-3609.

[11] Krile, S., Rakus, M., Schindler, F. Centralized Routing Algorithm Based On Flow Permutations. In: 39th International conference on Telecommunications and Signal Processing, 2016, pp. 68-73. ISBN 978-1-5090-1288-6.
[12] Cerna, L., Bukova, B. Supplier Evaluation Methodology in the Logistics Company. In: Proceedings of the 9th International scientific konference Transbaltica, Procedia Engineering, 2016, Vol. 134, pp. 377-385. ISSN 18777058.

[13] Fedorko, G., Neradilova, H., Sutak, M., Molnar, V. Application of Simulation Model in Terms of City Logistics. Transport Means - Proceedings of the International Conference, 2016, pp. 169-174, ISSN: 1822-296X.

[14] Kampf, R., Lizbetinova, L., Tislerova, K. Management of Customer Service in Terms of Logistics Information Systems. Open Engineering, 2017, Vol. 7, Issue 1, pp. 26-30. ISSN 2391-5439.

[15] Tomasic D., Jurcevic, M., Mavrin, I. Implementation of e-procurement system in function of supply optimization in the supply chain. Logi - Scientific Journal on Transport and Logistics, 2010, Vol. 1, No. 2, pp. 68-83. ISSN 1804-3216.

[16] Hou, B. The Optimizing Model of the Logistics Warehousing Distribution Based on RFID Technology. Internaional conference on Computer Science and Network Technology (ICCSNT), Vol. 1-4, pp. 2709-2711. ISBN 978-1-45771584-6.

[17] Seba, J., Hruska R., Svadlenka, L. Analysis of automatic identification and data capture systems use in logistics. Logi - Scientific Journal on Transport and Logistics, 2016, Vol. 7, No. 1, pp. 124-135. ISSN 1804-3216.

[18] Kubasakova, I. The technic as a component to organization warehousing areas. Logi - Scientific Journal on Transport and Logistics, 2011, Vol. 2, No. 1, pp. 33-38. ISSN 1804-3216.

[19] Jankowski-Mihulowicz, P., Kawalec, D., Weglarski, M., Lichon, W. Using the phased array antenna to increase geometric size of the interrogation zone in a UHF RFID system. Archives of electrical Engineering, 2017, Vol. 66, Issue 4, pp. 761-772. ISSN 1427-4221.

[20] Zitricky, V., Cerna, L., Abramovic, B. The proposal for the allocation of capacity for international railway transport. In: 12 th International scientific conference of young Scientists on sustainable, modern and safe Transport, Procedia Engineering, 2017, Vol. 192, pp. 994-999. ISSN 1877-7058.

[21] Sanchez, L., Ramos, V. Efficient Distributed Identification for RFID Systems. Wireless personal Communications, 2017, Vol. 94, Issue 3, pp. 1751-1775. ISSN 0929-6212.

[22] Kampf, R., Lorincová, S., Hitka, M., Stopka, O. Generational Differences in the Perception of Corporate Culture in European Transport Enterprises. Sustainability, 2017, Vol. 9, No. 9. ISSN 2071-1050.

[23] Fera, M., Macchiaroli, R., Fruggiero, F., Lambiase, A., Miranda, S. Application of a business process model (BPM) method for a warehouse RFId system implementation. International Journal of RF Technologies - Research and Applications, 2017, Vol. 8, Issue 1-2, pp. 57-77. ISSN 1754-5730.

[24] Geng, J. F., He, Z. L. Innovation and Development Strategy of Logistics Service based on Internet of Things and RFID Automatic Technology. International Journal of future Generation Communication and Networking, 2016, Vol. 9, Issue 12, pp. 251-261. ISSN 2233-7857.

[25] Bajor, I., Babic, D., Babic, M. I. Sustainability through greening and reversing the supply chain. Logi - Scientific Journal on Transport and Logistics, 2012, Vol. 3, No. 2, pp. 7-13. ISSN 1804-3216.

[26] Celebi, N., Savas, K., Selvi, I. H. Pricing Based on Real-Time Analysis of Forklift Utilization Using RFID in Warehouse Management. Encyclopedia of Information Science and Technology, 4th Edition, 2018, pp. 5490-5502. ISBN 978-1-5225-2256-0; 978-1-5225-2255-3.

[27] Mohammed, A., Wang, Q., Alyahya, S., Bennett, N. Design and optimization of an RFID-enabled automated warehousing system under uncertainties: a multi-criterion fuzzy programming approach. International Journal of advanced manufacturing Technology, 2017, Vol. 91, Issue 5-8, pp. 1661-1670. ISSN 0268-3768.

[28] Duan, SM., Xu, Y. Construction of Intelligent Logistics Warehouse Management Information System based on RFID Technology. Proceedings of the International conference on Education, Management, Computer and Society, 2016, Vol. 37, pp. 509-513. ISSN 2352-538X.

[29] Zhou, J. R., Zhang, H. J., Zhou, H. L. Localization of pallets in warehouses using passive RFID systém. Journal of central South University, Vol. 22, Issue 8, pp. 3017-3025. ISSN 2095-2899.

[30] Stopka, O., Bartuska, L., Kubasakova, I. Selecting the Most Suitable Region in the Selected Country for the Placement of the Bi-Modal Freight Village Using the WSA Method. In: Scientific proceeding for the conference ITELMS'2014, Kaunas, Litva, 2014. ISSN 2345-0088.

[31] Chen, J. C., Cheng, C. H., Huang, P. B., Wang, K. J., Huang, C. J., Ting, T. C. Warehouse management with lean and RFID application: a case study. International Journal of advanced manufacturing Technology, 2013, Vol. 69, Issue 1-4, pp. 531-542. ISSN 0268-3768.

[32] Fedorko, G., Liptai, P., Molnar, V. Proposal of the methodology for noise sources identification and analysis of continuous transport systems using an acoustic camera. Engineering failure Analysis, 2018, Vol. 83, pp. 30-46. ISSN 1350-6307.

[33] Vojacek, A. Používané RFID frekvence a jejich vliv na čtení a zápis tagu. [online] Available via: https://automatizace.hw.cz/komponenty-prumyslovesbernice-a-komunikace/vice-i-mene-bezne-rfid-frekvence-a-jejich-vliv-navlastnosti-tagu.html. 